\title{
ACTORS THAT AFFECT PLACE-IDENTITY TRANSFORMATION OF A TRADITIONAL SETTLEMENT IN THE AGE OF GLOBAL TOURISM THE CASE OF SANUR IN DENPASSAR-BALI
}

\author{
Nyoman Gede M aha Putra* \\ Georgia Butina Watson** \\ Regina Mapua Lim***
}

\begin{abstract}
There are various arguments that revolve around the fact that place-identity influences aspects of human life: social, economic and political. A city with a strong place-identity is claimed to have stronger social cohesion among its population, better economic opportunities as well as stable political circumstances. The wave of globalisation which influences all parts of the world leads cities around the globe to adopt similar patterns of homogenisation. This makes cities look similar to one another and blurs their placeidentity. In order to maintain their character, many local authorities have tried to find appropriate solutions, because the global forces can not be curbed. Moreover, as a living space, a city is always on the move in accordance with the dynamics of its inhabitants. Although it is unimaginable to see a city without any progress, the cities hold some values that form their place-identity, construct their characters as well as make them attractive. For its unique features, the values regularly fascinate tourists, creating economic opportunities. However, tourism businesses may also influence the place-identity construction of the cities. This paper analyses the transformation of place-identity of an area rooted in tradition in Bali. Urban morphology study and qualitative interviews were conducted to analyse the continuity and change of urban components. Today, physical development that supports tourism sector influences the vernacular processes of the place. Some values are maintained by the locals but they also need to adopt global phenomena as a negotiation between being rooted as well as being part of the global tourism industry needs development. The
\end{abstract}

negotiation, however, should not compromise the preservation of natural resources and the rituals, because these factors are as the essence of tradition by the locals.

Keywords: Place-Identity, Tradition, Tourism, Urban Morphology, Bali

\section{INTRODUCTION}

In an age of globalization, it is claimed that place-identity is no longer important because the global sense of place is taking over. But, despite being interconnected and crossinfluencing one to another, many places still maintain their unique characters and, therefore are still interesting for many. Visiting unique places has become an industry called tourism. It is supported by advancement in transportation and communication technology, with which one can visit places all around the world. Involving great amount of capital and producing considerable economic profit, tourism has been growing as global business. The more unique a place is in the eyes of the tourists, the more interesting it is to visit and, therefore, the better economic opportunities it has. Thus, place-identity is still relevant in a borderless world. However, tourism industry may bring drawbacks to local places. The increasing number of visitors necessitates great amount of lands which, in turn, changes the traditional cultural landscapes that were once serving only local inhabitants. Not only the physical, but also the perceptual components of the place may change. Parts of a place that are important and meaningful for locals but less attractive for tourists might be manipulated. This could transform the

* Nyoman Gede Maha Putra, Universitas Warmadewa, Denpasar-Indonesia. Email Correspondance: gedemahaputra@hotmail.com

** Georgia Butina Watson, Department of Planning Oxford Brookes University. Email Correspondance: gbutina-watson@brookes.ac.uk

*** Regina Mapua Lim, Department of Planning Oxford Brookes University. Email Correspondance: rlim@brookes.ac.uk 
place-identity of a traditional place rooted in tradition. Traditionally, many places in Asian and African regions were once independent and managed by traditional leaders. During and after the colonialism those places were managed under one national system that weakened the role of the traditional administrations. Decisions made by higher government levels transformed the place-identity. Moreover, when it comes to global economic activities, place-identity might change more easily, because investment that backs development moves borderless.

An attractive place that invites tourists is in turn also attractive to people to seek jobs. The problems of population growth need to be addressed by developing more houses and facilities. To build more houses, more materials and better construction methods are needed. New resources and materials, transported from different places, are replacing the more traditional building materials. This is followed by the utilization of non-traditional building and construction technology. Moreover, in education curricula, the adoption of modern literature facilitates the transfer of ideas and overshadows the traditional transmission process of traditional knowledge (Watson and Bentley, 2007; Brislin, 2012; Pallasmaa, 2012).

The debates about place-identity today are focused on the issues of urban transformation where cities across the world, despite being situated in different locations, tend to be developed in similar ways presenting the processes of homogenization (King, 2012). Global network systems, where transfers of capital and resources on an international scale, influence the creation of local places. Moreover, the global information system has redefined the interaction between people and place (Sassen, 2011). Losing the sense of identity is very destructive. It can weaken the sense of stability, meanings and settings for face to face interaction between people and between people and places (Castells (b), 2009). What is more, it could also diminish the attractiveness of the place for visitors.

This paper explores the transformation of a traditional place, the Village of Sanur in Bali, that has turned into a touristic place. In order to serve the business, many components of the settlements have been developed. But some elements are sustained by the inhabitants for the value and meanings they hold. Nowadays, tourism outweighs agriculture, the original raison of the village, as the main source of income. Despite providing better job opportunities, the skyrocketing speed of tourism development threatens the society because it may loose its identity. The inhabitants are now in two minds, should they retain the traditional characters or accept the international trend in order to host more tourists? A negotiation platform that could bridge the gap is needed.

\section{Background: Place-identity Transformation}

The traditional people saw themselves as an inseparable part of nature, and of the context in which they lived. The elements of nature were taken into account when organizing living arrangements, arrange purpose, and giving meaning to their life by structuring them into a constructed symbol of the cosmos or the cosmology. As a part of nature, human beings should traditionally fit into this scheme and follow the principles of how nature works.

In the pre-industrial era, the traditional landscape was managed and developed in a way that gave local inhabitants full control over their territory. The cultural activities and economic means of these people were developed to serve local needs and were influenced by the distinctive characteristics of local natural resources (Bourdier and AlSayyad, 1989). Construction methods were transmitted from one generation to the next ensuring the continuity and stability of the traditional form-production processes (Oliver, 2006). Therefore, the traditional settlement fitted culturally and technically with the culture and local climate (Rapoport, 2005), blending in with the environment (Tuan, 1977; Oliver, 2006). In such situations, the relationship between a person and a place is not just between oneself and one's surroundings, but it has to do with a much deeper process of identification where people create a friendly association with a particular environment (Relph, 1976; Lynch, 1984; Watson and Bentley, 2007). By this identification, people are able to distinguish one place from another, yet this relationship builds a placeidentity from which people can define who they are both as individuals and as community members (Southworth and Rugeri, 2010).

Socio-political transformation changes the way places are used and experienced. Colonialization channeled new ideas originating in the West to the vernacular landscape of the East. During the colonial era, many traditional cities in Asian and African regions were redeveloped with non-traditional ideas, to serve colonial motives of wealth creation. It influenced the concept of local cosmology, restructured traditional socio-political landscape, expanded local market, yet introduced local economy to international exposure. In turn, the physical arrangements of the traditional landscape of the East were transformed. The long span of colonialism guided the creation of a global economic system, which facilitated the transfer and adoption of dominant western ideas (King, 1991). As a result, homogenization emerged everywhere. 
Issues of modernization versus tradition are also debated in Denpasar, Bali in the Republic of Indonesia, an area which was colonized by the Dutch for centuries (King, 1991; 2012). In order to create wealth, the colonial government constructed ports and expanded local markets to serve wider areas, which then transformed the configuration of the urban landscape. Whilst considerable and immediate changes occurred in the city center, the general cultural landscapes remained unchanged, because they were managed and controlled by the indigenous people possessing traditional knowledge. The tensions of power representation created dual-characteristics of the city in the colonial period (Colombijn, 2006). Later on, the distinct characteristics of the island, with thousands of temples, unique socio-cultural traditions, settlements and distinctive natural landscapes, were preserved and capitalized upon by the colonial government to promote tourism (Powell, 1982; Covarrubias, 1999; Picard, 2008). The economic motives of the colonial government both changed and preserved the island's local character.

Concerns regarding place-identity entered a new dimension of tensions of political representation, when the political power shifted from the colonial to a national government. In the post-colonial era, Sanur was managed under the political system of the new state. Denpasar was chosen as the capital of Bali Province, under the three governance levels of the Republic of Indonesia: national, provincial and municipal. Consequently, new city governance was introduced and new facilities were constructed. The dualcharacteristics in the governance system continued, because the traditional people sustained their traditional administrative influence on the place-identity of the city. This dualcharacteristics could also be seen in the physical development of the city as shown in (Figure 1).

Nowadays, changes that take place on a global scale occur more rapidly. The homogenizing impacts of these changes on local places are sometimes considerable. Some critics claim that the process of homogenization is about domination and resistance (Edward and Usher, 2000; Castells, 2009). On the other hand, dominant institutions may introduce their ideas of place-identity in order to extend and rationalize their domination. Meanwhile, those being stigmatized by the domination may build trenches of resistance (Castells, 2009). Tensions occur when modern and traditional ideas are not fused with one another. In contrast to the traditional period where the indigenous people held full control, a city in the contemporary context presented different contestations of power that influenced its form and transformation (Harvey,

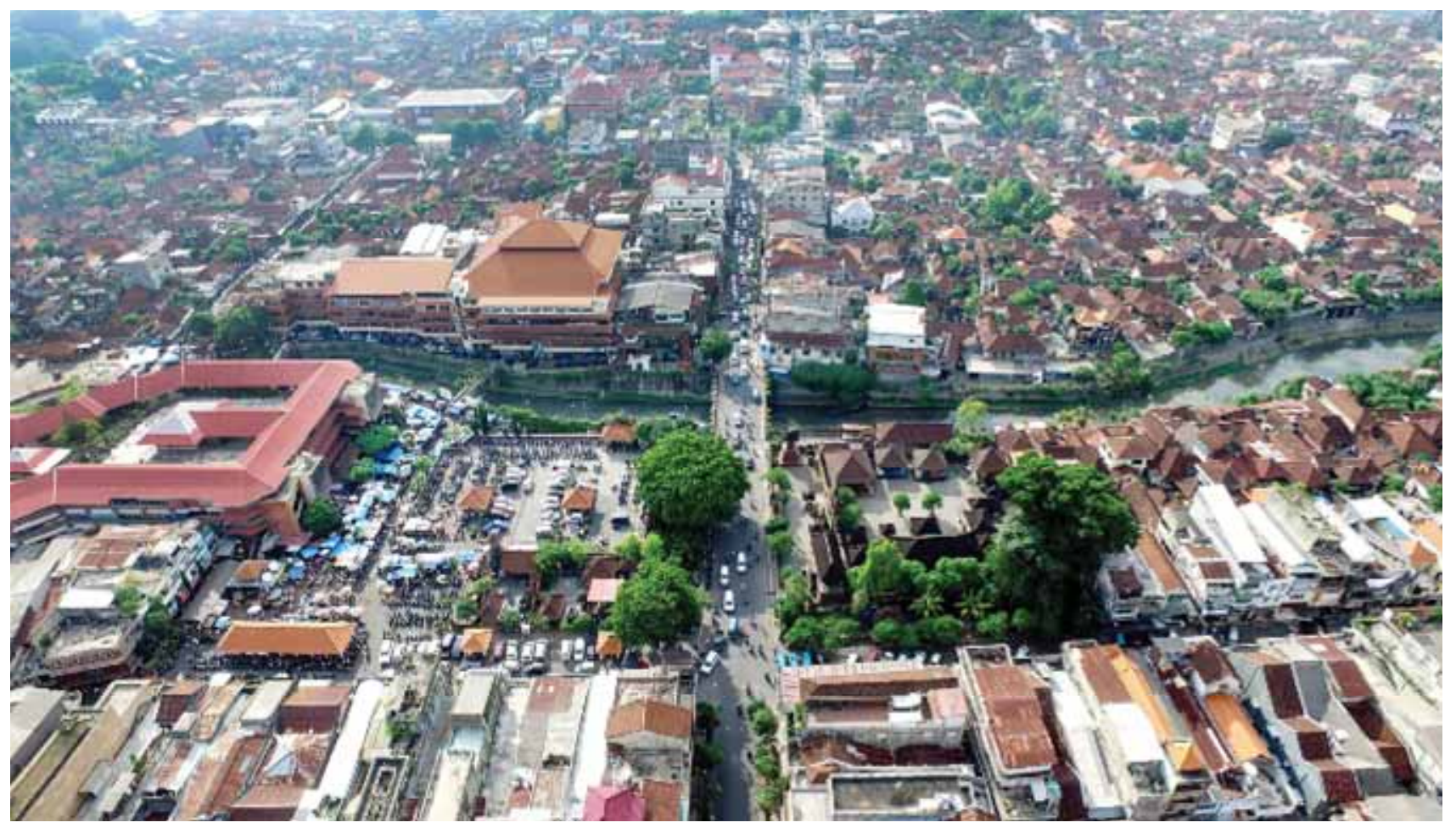

Figure 1: New building typologies: the larger buildings in the middle of the image were built by higher level government, while the smaller buildings belong to the indigenous people.

Source: Fieldwork, 2014 
1997). The sense of powerlessness may grow and cause anxiety and fear if the society cannot manage the city's transformation (Madanipour, 2013). It is also important to consider the society members in managing change and defining place-identity of the city.

\section{Urban Morphology as a Method of Researching Place- identity}

Tradition influences place-identity of cities as they progress. As a complex and dynamic system, a city comprises many dimensions and elements which are linked to one another, being created and recreated continuously by its inhabitants within its lifespan. Given that the interaction between people and place involves evaluative processes, changes in physical characteristics also influence the behavior of people and vice versa. Urban morphology study is capitalized upon in this research to analyze the evolving physical forms and socio-spatial structure of the city (Conzen, 1960; Whitehand, 1990; Kropf, 2009; Larkham and Conzen, 2014).

Firstly, it is important to evaluate meaningful traditional invariants of the city in order to understand the rooted values of the city. Secondly, the development phases of the city should be researched to evaluate the evolution of the sociospatial and physical components of the city. Thirdly, in order to identify individual and social meanings as well as to formulate strategies to manage their transformation, local perceptions and the roles of different key urban actors in the form-production processes should also be analyzed. In order to develop an innovative negotiation platform where tradition and modern could be exchanged, an Inquiry by Design method is applied to test some prepositions with the local inhabitants of Sanur.

\section{Discussion and Analysis: Transformation of Sanur from an Agricultural Traditional Village to a Cosmopolitan Tourist Destinatio: The Origin of Sanur}

Orientation and identification are two elements that constitute 'the spirit of place' (Norberg-Schulz, 1980). In Bali, orientation and identification are important elements of the traditional cosmology (Eisemann, 2010). They are utilized in almost every single action of people, from arranging the public facilities of a village to their daily activities. To create a sense of orientation, the natural geographical characteristics and the path of the sun are used. For traditional people, the highlands of Bali possess practical and symbolic meaning. The colossal size of the mountains, particularly the highest peak of Mount Agung, makes them visible from all over the island. Four lakes that are located on the highlands stream continuous water to the rice-fields. Instead of posing a threat, the highlands provide a point of orientation and a source of water for agriculture. For this reason, the highlands are preserved and believed to be the dwellings of the ancestral spirits and gods. The sea surrounds the island from all directions and is embedded with negative meanings. Demons, evil spirits and impure soul dwell in the ocean and make it a haunted place. Moreover, areas close to the body of water of the sea are usually not fertile and less valuable for agriculture. But these areas are also preserved to protect the dwelling areas from the threat of the ocean.

People have developed a sense of orientation and live in various locations on the island, between the two contrasting geographical elements of the mountains and the sea. The mountainous areas, the plains and the ocean construct a division of three: north-center-south (Eisemann, 2010). Meanings embedded with these directions create a ritual axis. The path of the sun is also considered in the construction of the sense of direction and is utilized to arrange daily life. The direction where the sun rises is seen as a symbol of birth, in contrast with death which is symbolized by the direction where the sun sets. The direction where the sun rises and sets constructs the east to west axis. The time between these two opposing directions forms the third division consisting of morning-midday-afternoon. The superimposition of the highlands-sea and sunrise-sunset axes constructs a scheme of four and the central point, generates basic directions: north, south, east, west and centre. The intermediate directions add four more values, leading to eight directions and a centre. These eight directions and the centre are called the Nawasanga, a scheme of the nine powerful directions of the supreme God (Gelebet, 1986; Sularto, 1987; Eisemann, 2010).

It is believed that humans possess a small part of the god, called the spirit or atman which occupied the middle world during his/her life. An atman may travel to the under and upper-world. The atman will stop traveling once he/she achieves moksha, a condition when the spirit merges with the universe, the ultimate goal of the Hindu-Balinese people. This belief system constructs the three world layers (Eisemann, 2010). Humans dwell in the middle between the upper and the underworld.

Figure 2 presents the perceived world of Bali. The middle world, the blue ellipse in the middle of the image, is where humans dwell, constructed from the mountain-sea axis and the path of the sun. The upper world is occupied by the purified spirits of ancestors and the underworld is occupied by the impure spirits. This scheme creates the value system 


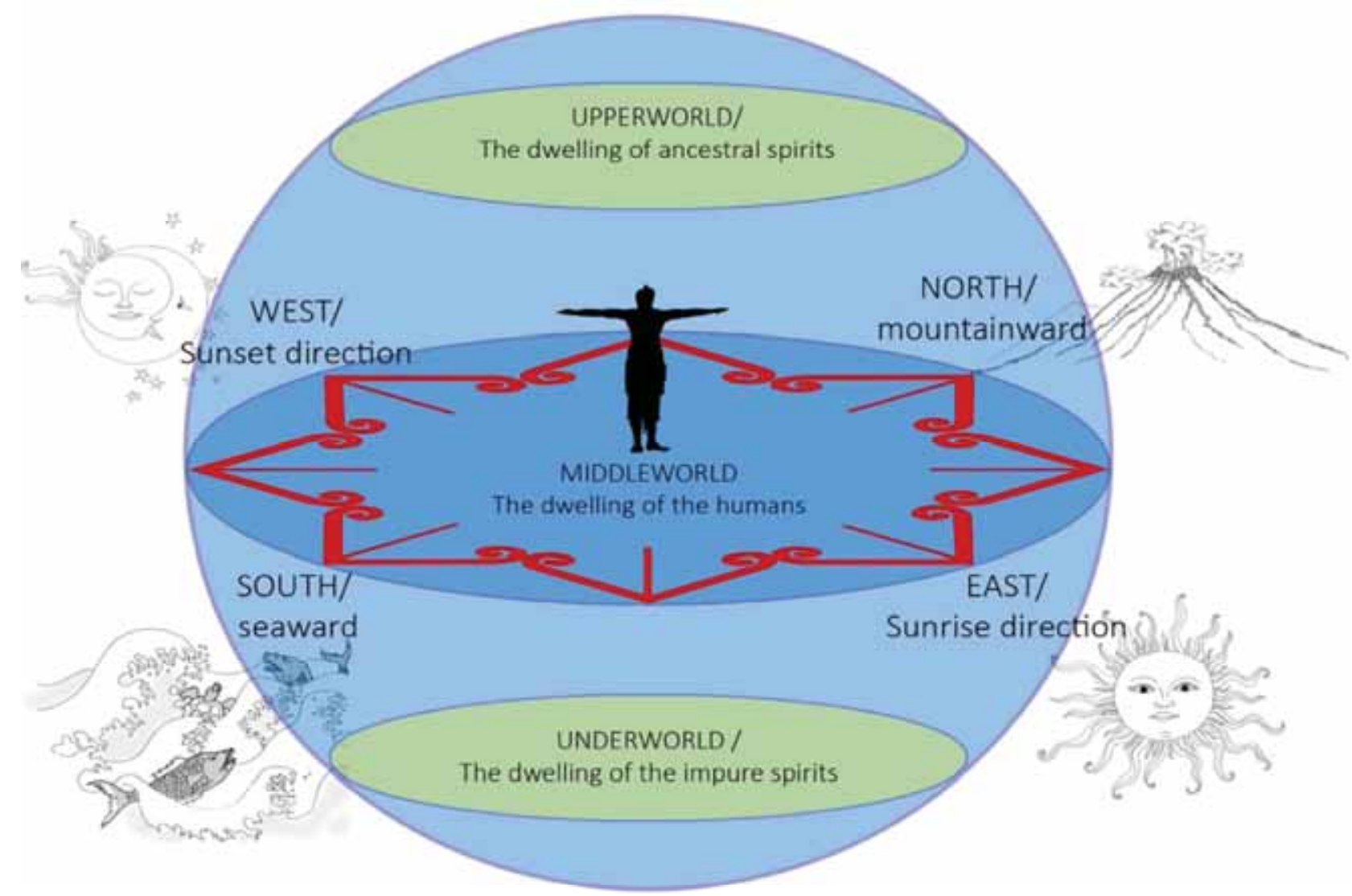

Figure2: The scheme of the perceived world of Bali consists of eleven parts constructed from God-given elements Source: Constructed by the author after Gelebet, 1986; Lansing; 2006, Howe L., 2006; Eisemann, 2010

that is used to guide the daily life of the Balinese people and it constructs meanings. It is implemented at different scales: from laying out a village to arranging daily life following the principle of 'small world' and 'big world'. A human is the small world in his house, the house is the small world of a settlement and the universe is the big world of the settlement.

A prosperous life can be achieved if all the elements of the perceived world are in harmony. In order to do so, the traditional society maintains the three different elements of a settlement, both physically and ritually.

Sanur is located on the eastern part of the City of Denpasar on the Island of Bali. The geographical characteristics of the area influence the construction of the local cosmology. Geographically, the area consists of: infertile sandy areas; less fertile areas; and the fertile areas located furthest from the beach. Water sources are respected for their importance in providing irrigation for the people working as traditional farmers. The settlement is arranged between the beach and the fertile lands, with respect to the upstream and downstream axis.

The traditional socio-political situation of the area is shaped by the old social structure of the society. The settlement was established by a group of traditional people led by a priest. To run the village's governance, the priest was assisted by the members of the society arranged in several banjars. The political structure of the settlement consisted of the two levels, the village and banjar. The priest led the decisionmaking process based on a democratic public participation mechanism at the banjar level. The majority of the traditional people worked on the farmland, and only went to the sea in their spare time. The infertile land on the beachfront was seen as containing less economic value because it could not be cultivated. Guided by cosmology, the overall area was divided into three different economic zones having different economic values: fertile farmland, dwelling areas and infertile sandy areas (Figures 3 and 4).

In terms of spatial and physical arrangements, the buildings were designed in human proportions in order to provide 


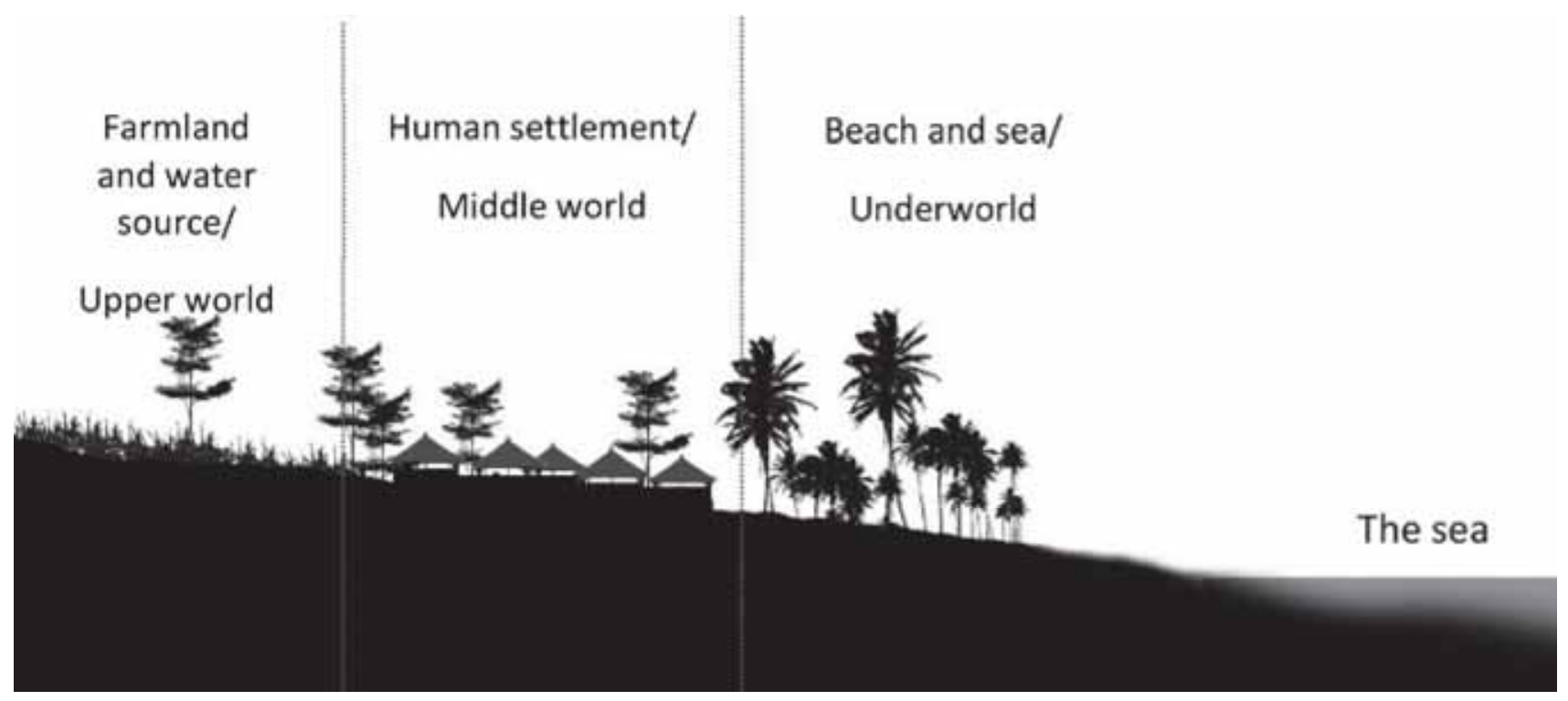

Figure 3: The settlement is sandwiched between fertile lands and infertile lands. Source: Constructed from transect walks and observation



Figure 4: Distribution of three layers of perceived world and its relationship to site characteristics Source: Constructed from Google Earth map, transect walks and interviews 
structural stability as well as express symbolic meanings. The head, the body and the feet were represented by three building elements: the pyramidal roof, the space under the roof and the solid base. The overall proportions of traditional buildings gave a sense of stability and with the traditional carpentry and construction methods, they were resistant to earthquakes.

Local materials and construction methods all responded to the local climate and characteristics. The application of these principles created a pleasant environment for the inhabitants, yet was also culturally appropriate. Over the years the authenticity of the area has become the main attraction for foreign visitors. Moreover, the warm white-sandy beaches of Sanur, that were once seen as infertile land, today attract tourists in large numbers, especially from cold countries.

\section{Sanur in the Age of Tourism}

Tourism started to flourish since the colonial government exposed the island to international audience in the 1920's. Tourism sector was also capitalized upon by the new government of the Republic of Indonesia to increase economic benefit. This strategy, however was a top down policy led by the national government.

The socio-political structure of the area has changed under the Republic of Indonesia. It is managed as one of the administrative villages within the South Denpasar District. Consequently, the development of the area has been carried out in accordance with the plans of the upper level government. However, two governmental bodies exist and manage the area because the traditional administration continues.
The formal government capitalized tourism to support local and national income. For that reason, a study to manage this sector was conducted in 1969. The study suggested developing unproductive areas and protecting the fertile land on the island (SCETO, 1974). In this respect, it was recommended to develop areas on the beach that held less value for the indigenous people. To support this strategy, infrastructure works were carried out including the development of an international airport and a by-pass road. The airport and the roads facilitated the increasing number of tourists. This in turn improved the local economy, intensifying the new development dominated by provision of tourist facilities.

The economic growth seems to have become the lingua franca of the area in the tourism era, replacing the cosmological approach of the traditional era. Facilitated by the formal government, many investors are interested in building businesses in the area. Hotels and restaurants have developed in various locations. Over time facilities to support tourism have also been established on the fertile farmlands.

The increasing development trend to support tourism has boosted local economic development, and has potentially caused tensions among different users. The better economic opportunities offered by the new businesses have attracted local people to move from agricultural occupations to the tourism sector, as working in the tourism sector is perceived as more promising economically. As a result, the fertile land has been abandoned and agriculture as the root of local tradition is neglected. The tourism industry has modified the economic value of the land. Agriculture as an occupation is seen as outdated. In contrast, land on the beach is perceived as more valuable (Figure 5).

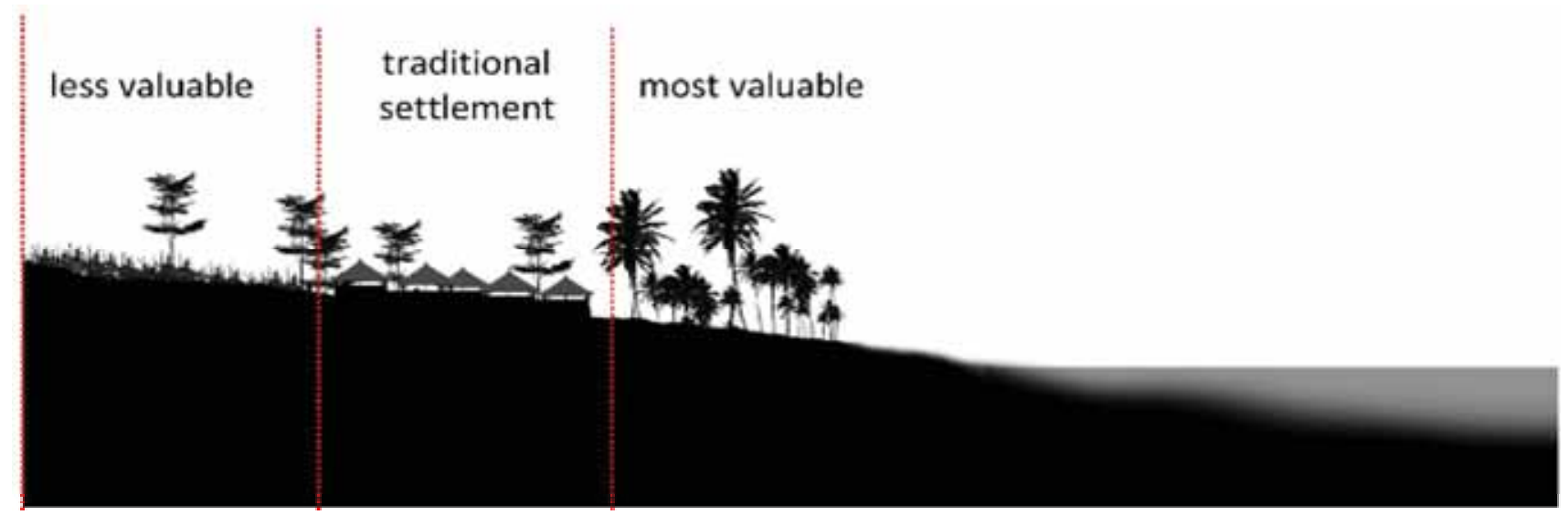

Figure 5: The changing economic value of land in Sanur

Source: Constructed from transect walks, Observation and interviews 
The increasing appeal of the area has also invited migrants, generating urbanization. Statistical data show that, in sixteen years, from 1993 to 2009, the amount of agricultural land use has dropped from eighty one hectares to twenty two hectares (Bappeda, 2011). Annually, 1.38 hectares of farming sites are transformed into built forms. If the trend continues, all farmland may vanish by 2025 (Bappeda, 2011a).

The new economic means have provided the locals with better economic income. However, it is also impacting local place-identity, based on agriculture. Four maps in figure 6 show the morphological development pattern of Sanur and should be read from the bottom to the top. The bottom map shows the original linear pattern of the settlement. It is located within an adequate distance from the beach and close to the farmland. In the second map, the road construction, which has taken place to support tourism development divides the area into two distinct areas, where the waterfront is packed with commercial facilities for tourists. The growth of tourism has increased the economic attraction of the settlement and, as shown in the third map, a ribbon development of commercial facilities has emerged on both sides of the road. These economic activities have brought migrants into the area. Today, the area has become a mix of a traditional settlement and an area characterized by tourism and commercial facilities, as well as new residential neighborhoods for the migrants. The introduction of tourism has changed the economic base of the settlement, which in turn has impacted the traditional settlement patterns based on cosmology. Some local people have maintained the local beliefs which have been in place for centuries. The convergent shape of the original dwellings is now merging with the organic patterns formed by the new economicbased activities. The next section analyses how this transformation is perceived by the locals.

\section{Local perceptions on the development of Sanur}

The sustainability of traditional characteristics of the area and the increasing economic growth are appreciated by the respondents. The locals embrace new economic activities on the beach. They claim that new investment supports local businesses and enlivens the settlement. With the money, the locals can conduct traditional rituals periodically. The longestablished traditional rituals maintain the sense of rootedness of the indigenous people and the resilience of the traditional cosmology, and therefore, strengthen the identity of the place.
However, the rapid development on the former rice fields and the shrinking number of open spaces were criticized. It was argued that the spatial and physical developments should be managed in a better way. The growing numbers of new settlements on the farming sites not only reduced the sense of rootedness of the area, but also diminished open spaces. The overcrowding and the limited open spaces decreased the opportunities for the community members to create shared positive experiences and memories of their place of residence. Moreover, it was also pointed out that the new development patterns were not respecting the natural geographical characteristics of the area. This resulted in the imbalance of the cosmological order of the area. The complaints and criticisms regarding the development trends signified that the locals and the traditional government had no means of influencing the decision-making process. The locals were powerless because the development was dominated by powerful urban actors focusing on producing economic benefits. These powerful actors were the investors and the formal government who set up the economic policy. In order to transfer adequate power to local inhabitants organized in traditional society, a better decision-making process is required to be constructed.

\section{A Negotiation Platform for Negotiating Tradition and Modern}

From the analysis, it was clear that the transformations of Sanur were respected for the economic benefits it bought. But it was criticised as giving less opportunities for locals to involve themselves in the development of the area. Therefore, although the locals enjoyed better income, they also complained about certain development patterns that were abandoning traditional cosmology. Based on the appreciation and criticism by the locals, key urban design principles as negotiation platform were formulated. These principles were constructed on four dimensions of cosmology, socio-political and economic, spatial and physical, and sociocultural dimensions. The principles of the platform are:

1. Negotiating traditional cosmology with the contemporary ways of life

Place-identity in the city is rarely a single interpretation. It tends to be open to multiple interpretations because it not only resides in the physical components and observable activities, but also in human perceptions (Carmona, Heath, and Tiesdell, 2010; Southworth \& Rugerri, 2010; Hague and Jenkins, 2004). 

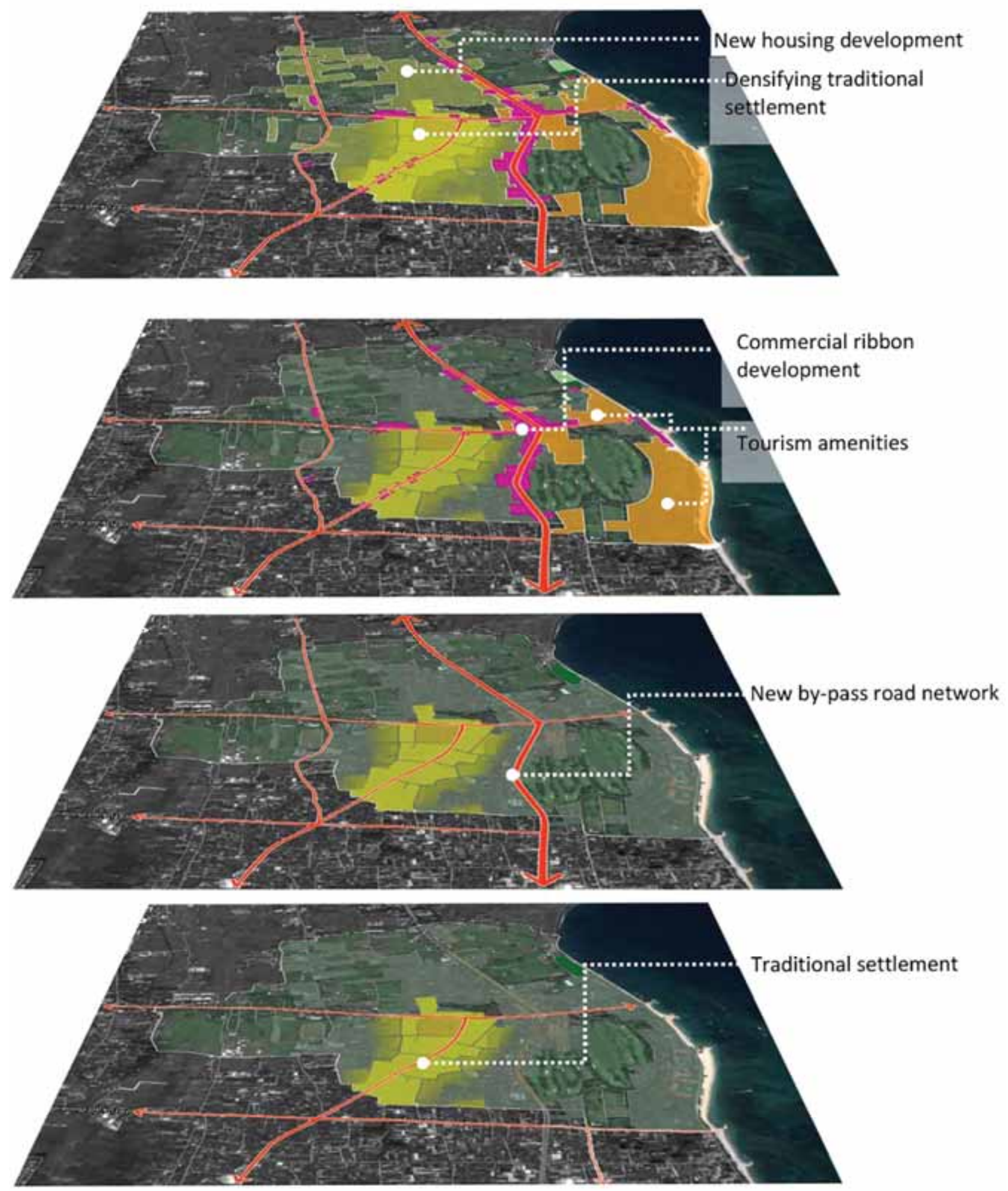

Figure 6: Morphological development layers of Sanur

Source: Constructed by the author based on Google Earth image, fieldworks and interviews 
In the contemporary city of Denpasar, the perceptive component that constructs place-identity is more complex because it is influenced by the mixed demographic composition of the society: indigenous groups and nonindigenous; older and younger generations. Each individual and group may develop different ideas, experiences and memories which influence their perceptions. This situation is different from the traditional period when the area was home to and used by traditional people from a homogenous cultural background and who had limited choices. Nowadays, the local cosmology, which was once the supreme value used to validate choices, is challenged by the contemporary way of life because it is embedded only with the indigenous people. However, the cosmology, which is based on traditional ways of perceiving the elements of nature and the way they work, is still relevant because it assists the diverse inhabitants to live in harmony with nature. Therefore, the traditional cosmology should be translated to incorporate a wider audience. It could be used as the new supreme value to validate the different choices of the diverse demographic compositions of the city in the contemporary context, because all society members are part of the city's universe, regardless of their differences. All individuals and groups need to be encouraged to live in harmony with the wider ecosystem called 'nature'.

2. Negotiating the traditional socio-political and economic structure with the contemporary urban governance and commercial activities

In the construction of place-identity, a democratic and open process is suggested because access to shared meanings is political (Hague \& Jenkins, 2004; Madanipour, 2013). The democratic process gives wider access to community members to participate in the construction of their individual and collective identity. Participating in the construction of place-identity may strengthen the sense of belonging and attachment that people have to the place where they live.

Therefore, it is suggested to formulate an open planning framework where all actors can participate in the formproduction processes of the area. In order to develop a shared vision, this planning platform should incorporate: the members of the society, the traditional administration, traders and farmers, the formal government, and investors and developers. This shared vision will provide a platform for all actors to participate in without being excluded; feeling excluded may increase a sense of powerlessness.

3. Negotiating the traditional spatial and physical arrangement with the new spatial and physical development.
Place-identity will be stronger if meaningful activities and strong visual forms are combined (Southworth and Rugerri, 2010). Modern neighborhood developments which devalue existing traditional forms have often been blamed for the production of meaningless places (Norberg-Schulz, 1980; Oliver, 2006; Pallasmaa, 2012). In order to avoid this, the existence of the traditional settlement and the need for new physical development should be negotiated.

The preservation of the traditional spatial configuration, however, should not limit opportunities to develop new dwelling units in order to provide a wider choice of housing. In developing new housing units, traditional value systems should be referred.

4. The socio-cultural dimension and the promotion of the creation of positive experiences and shared memories.

Socio-cultural activities occur in public spaces. In the traditional society, these activities were sustained by the traditional people; therefore, places for rituals and traditional ceremonies were preserved. In the contemporary context, these activities still only include the indigenous people. In order to involve the non-indigenous members of the society, more public spaces and social occasions should be promoted.

The provision of public open spaces with adequate facilities and events should be encouraged. Secondly, because place is not just a physical setting, but it is also about what it means to people, the provision of public spaces should be followed with the promotion of social activities. The availability of adequate open spaces with communal activities that involve all community members regardless of their different backgrounds and age groups could support the construction of positive shared experiences and memories.

\section{Conclusions}

The paper explores the concept of place-identity in the context of a traditional yet rapidly developing city and has linked theoretical concepts, methodological frameworks and empirical evidence in the contemporary context of Sanur area in Bali, Indonesia. The study has also sought to know how place-identity can be sustained in the contemporary context whence flows of ideas and resources at global scale threaten local places.

Global flow of ideas could not be curbed in the age of globalization. This may change place-identity of many places across the globe. However, places that offer unique placeidentity attract tourists. Therefore, place identity is still 
relevant. Maintaining the place-identity of a touristy place is not an easy task. A traditional place that once was developed and managed by small group of people is nowadays packed inhabitants of diverse backgrounds, managed by multi-level government bodies and developed by non-traditional investors. Because place-identity is structured not only from physical forms but also human perceptions, new ideas, social structure and demographic composition, and social relation influences place-identity of a traditional yet rapidly developing place. In order to maintain and sustain the placeidentity of the place, this paper suggests a negotiation platform consists of four components. Firstly, is the negotiation of the traditional cosmology with the contemporary ways of life. The second component is the negotiation between different socio-political and economic actors. While the third negotiation is encouraged between the old and new physical development, the promotion of social activities to shape shared memories and experiences is suggested as the fourth negotiation.

The components that construct place identity is in a state of constant revision, therefore, place-identity is dynamic. In order to get benefits from place-identity, it should be constantly researched and strategies to maintain it should also be periodically revised. This will keep place-identity of a rapidly developing city up to date.

\section{REFERENCE}

Bappeda, K. D., 2011, M ateri Teknis Rencana Rinci Kawasan Strategis K ota Denpasa, Denpasar, Wartha Bhakti Mandala. Bappeda, K. D., 2011a, Rencana Tata Ruang Wilayah Kota Denpasar 2011-2031, Denpasar, Pemerintah Kota Denpasar. Bourdier, J. and AlSayyad, N., 1989, Dwellings, Settlements and Traditions: Cross-cultural Perspectives, Lanham, University of Minnesota Press.

Brislin, P., 2012, Human Experience and Place: Sustaining I dentity, London, John Wiley and Sons.

Carmona, M., Tiesdell, S., Heath, T. and Oc, T., 2010, Public Places U rban Spaces:The Dimensions of U rban D esign, 2nd ed., London, Routledge.

Castells (b), M., 2009, The Rise of the Network Society: Information Age, Economy, Society and Culture: 2 (Information Age Series), West Sussex, Wiley Blackwell.

Colombijn, F., 2006, "Planning and Social Tension in Indonesian Cities", Global Bioethics, vol 16: 73-84.

Conzen, M., 1960, Alnwick, Northumberland: A Study in Town Plan Analysis, London, Institute of British Geographers.

Covarrubias, M., 1999, The Island of Bali, Hongkong, Periplus.

Edwards, R. and Usher, R., 2000, G lobalisation and Pedagogy: Space, Place and Identity, Oxford, Routledge.

Eisemann, F. B., 2010, Bali Sekala and NIskala: Essays on Religion, Ritual and Art, Singapore, Tuttle Publishing.

Gelebet, 1986, Arsitektur Tradisional Daerah Bali, J akarta, Dinas Pendidikan dan Kebudayaan Republik Indonesia.

Hague, C. and Jenkins, P., 2004, Place-Identity, Participation and Planning, London, Routledge.

Harvey, D., 1997, “Contested Cities, Social Process and Spatial Form”, In: Transforming Cities, London, Routledge.

Howe, L., 2006, The Changing World of Bali London, Routledge.

King, A. D., 1991, Culture, G lobalisation and the World System: Contemporary Conditions for the Representasions, London, Palgrave MacMillan.

King, A. D., 2012, “Globalisation and Homogenisation: The State of Play”, In: H omogenisation of Representations, Geneva, Aga Khan Award for Architecture, pp. 17-34. 
Kropf, K., 2009, “Aspects of Urban Form”, U rban M orphology, 13(2): 105-120.

Lansing, S. J., 2006, P erfect Order: Recognising Complexity in Bali, Princeton, Princeton University Press.

Larkham, P. J. and Conzen, M. P., 2014, Shapers of U rban Form: Explorations in Morphology Agency, London, Routledge.

Lynch, K., 1984, The Image of the C ity, Massachusetts, MIT Press.

Madanipour, A., 2013, "The Identity of the City", In: City Project and Public Space, U rban and Landscape, Perspective 14, Dordrecht, Springer.

Norberg-Schulz, C., 1980, Genius Loci: Towards a Phenomenology of Architecture, New York, Rizzoli International.

Oliver, P., 2006, Build to M eet N eeds, London, Architectural Press.

Pallasmaa, J., 2012, Newness, Tradition and Identity, In: P. Brislin, ed. Human Experience and Place: Sustaining Identity, London, John Wiley and Sons, pp. 14-21.

Picard, M., 2008, "Balinese Identity as Tourist Attraction: from Cultural Tourism (Pariwisata Budaya) to 'Bali Erect", (Ajeg Bali), Tourist Studies, 2(8): 155-173.

Powell, H., 1982. The Last Paradise: An American Discovery of Bali in the 1920s, first published in 1930 (ed.,) Oxford, Oxford University Press.

Rapoport, A., 2005, Culture, Architecture and Design., Chicago, Locke Science Publishing Company Inc..

Relph, E., 1976, Place and Placelessness, London, Pion Limited.

Sassen, S., 2011, “The Impact of the New Technologies and Globalization on Cities", In: The City Reader (5th ed.). London and New York, Routledge, pp. 554-562.

SCETO, 1974, “Bali Tourism Masterplan”, Paris, UNDP/IBRD.

Southworth, M. and Rugerri, D., 2010, “Beyond Placelesness: Place-identity and the Global City", In: Companion to U rban Design, London, Routledge.

Sularto, R., 1987, A B rief Introduction to Traditional Architecture of Bali: Some Basic Norms, Denpasar, PT. Atelier 6.

Tuan, Y. F., 1977, Space and Place: the P erspective of Experience, Minneapolis, Minnesota University Press.

Watson, G. B. and Bentley, I., 2007. I dentity by Design, London, Architectural Press.

Whitehand, J., 2012, "Issues in Urban Morphology", U rban M orphology, I(16): 55-65. 